\title{
Znaczenie audiowizualności w kulturze masowej na przykładzie spektaklu teatralnego w reżyserii Radosława Rychcika pt. Dziady
}

\begin{abstract}
Streszczenie
Praca skupia się przede wszystkim na analizie zmiany, jaka zachodzi w kulturze masowej, odkąd jej dystrybucja została zdominowana przez masowe środki rejestrujące. Do tej pory interakcje społeczne oparte były głównie na kontakcie bezpośrednim, jednak wraz z pojawieniem się zjawiska audiowizualności relacje międzyludzkie i rodzaj komunikacji diametralnie się zmieniły. Rozwój mass mediów i ich upowszechnienie sprawiło, iż kultura zaczyna być postrzegana jako produkt zaspokajający nasze potrzeby i sprawiający przyjemność. W pracy pojawia się stwierdzenie, że mimo wszystko nie da się uciec od kultury masowej, która stała się już w zasadzie kulturą obecnie panującą, w której każdy z odbiorców jest zanurzony. Także każdy wytwór owej kultury jest produktem kultury popularnej i dawniej obowiązujący podział na kulturę niższą oraz wyższą generalnie przestał funkcjonować. W nowo obowiązującej rzeczywistości kultury masowej pojawia się pytanie o miejsce teatru jako sztuki opartej na bezpośrednim kontakcie aktora z publicznością i zawartej między nimi umowy społecznej, obowiązującej na czas przedstawienia. Jednak analiza przedstawienia pt. Dziady pokazuje, że sztuka teatralna doskonale odnajduje się w popkulturowej rzeczywistości, wykorzystując do tego audiowizualność.
\end{abstract}

1 Katarzyna Wnukiewicz, Wydział Pedagogiczny, Uniwersytet Warszawski, Polska, e-mail: katarzynawnukiewicz@gmail.com, ORCID ID: https://orcid.org/0000-0003-4734-0347. 


\title{
Słowa kluczowe:
}

audiowizualność, kultura masowa, kultura popularna, odbiorca, społeczeństwo, teatr

\begin{abstract}
The work focuses mostly on the analysis of change in mass culture, since its distribution has been dominated by mass media. Until now, social interaction was based primarily on direct contact, but with the appearance of audiovisuality, interpersonal relationships and the type of communication changed radically. The development of mass media and their dissemination has made culture to be perceived as a product that satisfies our needs and gives us pleasure. There is a statement that, after all, there is no escape from mass culture, which has become essentially a prevailing culture in which every consumer is immersed. Also, every product of this culture is a product of popular culture, and the former division of culture into a lower and higher culture, basically ceased to function. In the new reality of mass culture, the question arises about the place of theater, as the art of direct contact between the actor and the public and the social contract between them, valid for the time of presentation. However, the play "Dziady" shows that theatrical art perfectly finds itself in the pop culture, using audiovisuality.
\end{abstract}

\section{Keywords:}

audiovisuality, mass culture, popculture, receiver, society, theatre

Od wieków słowo pisane stanowiło główny nośnik myśli ludzkiej. Ma ono kluczowe znaczenie w gromadzeniu, przechowywaniu oraz przekazywaniu informacji, język naturalny przekształcił się w potężny system semiotyczny, który spełnia wszechstronne funkcje komunikacyjne (Hopfinger, 1997). Nie znano innej formy zapisu przekazu werbalnego, chociaż żywe słowo dalej pozostało głównym sposobem porozumiewania się ludzi w kontaktach bezpośrednich. Jednak wraz $\mathrm{z}$ wynalezieniem aparatu fotograficznego i ogromem zmian, jakie nastąpiły w XX wieku, komunikację społeczną zdominowały przekazy oparte na technikach rejestrujących obraz i odtwarzających audiowizualne aspekty świata. Taki nowy typ komunikacji utrwala świat człowieka i jego relacji z innymi, a także spaja wymiary wizualne i audialne, aspekty werbalne i niewerbalne.

Aby móc w ogóle poruszyć istotę audiowizualności we współczesnej kulturze, nie sposób jest pominąć tematu kultury masowej. Mimo że samo określenie, które od początku miało raczej znaczenie pejoratywne, zaczęło się kształtować 
w pierwszej połowie XX wieku, to zjawisko, które obejmowało ogromne zmiany społeczne, można było zauważyć już od przeszło stu lat. Hannah Arendt w eseju O kryzysie w kulturze i społecznej oraz politycznej doniosłości wyodrębnia dwa nowe pojęcia, którymi są społeczeństwo masowe oraz kultura masowa (Arendt, 2011). Dzięki rewolucji przemysłowej zaczęła poprawiać się sytuacja materialna niższych klas społecznych, które nagle zaczęły dysponować czasem wolnym, pozwalającym na obcowanie z kulturą. Pojawienie się kultury masowej wiąże się z przywłaszczeniem sobie wytworów kultury przez społeczeństwo masowe. Wraz ze wzrostem poziomu życia pojawiła się nowa potrzeba, którą jest konsumpcja. Niestety kultura stała się produktem. Arendt wprost nazywa ją „społecznym towarem, który może krążyć w obiegu i podlegać wymianie na wszelkie inne rodzaje wartości społecznych czy indywidualnych” (Arendt, 2011, s. 241). Społeczeństwo masowe nie pragnie kultury, a rozrywki. Towary, które są przez przemysł rozrywkowy oferowane, są konsumowane przez społeczeństwo niczym dobra spożywcze.

Arendt mimo negatywnego stosunku do zjawiska kultury masowej zdaje się nie widzieć w niej aż tak dużego zagrożenia, o którym pisze Dwight Macdonald w Teorii kultury masowej. Macdonald w tekście odnosi się do kultury masowej wręcz z nienawiścią, porównując ją do rakowatej narośli. Dokonuje sztywnego podziału na kulturę wyższą oraz kulturę niższą, wywodzącą się bezpośrednio z kultury ludowej (Macdonald, 1953). Używa także zamiennie terminu „kultura popularna” jednak jednoznacznie daje do zrozumienia, że określenie „masowa” bardziej pasuje do sytuacji, kiedy to wytwory kultury porównuje się do towaru, który jest hurtem rzucany na taśmę. Macdonald pisze o kulturze zhomogenizowanej, czyli przystępnej dla każdego członka społeczeństwa. Wartości reprezentowane przez te typ kultury z założenia są proste, ogłupiające i wulgarne.

Nie ma wątpliwości, że spostrzeżenia zarówno Arendt, jak i Macdonalda przyczyniły się do pogłębienia wiedzy na temat kultury masowej, a także zwróciły uwagę na jej zaistnienie w ogóle. Jednak współcześnie nie możemy już w tak klarowny sposób dzielić kultury, jak życzyłby sobie tego na przykład Macdonald. Granica między kulturą wyższą a kulturą masową całkowicie się zatarła i można jednoznacznie stwierdzić, że obecnie jesteśmy całkowicie zanurzeni w kulturze popularnej. Bardzo użytecznego podsumowania dokonał Marek Krajewski w swojej książce Kultury kultury popularnej. Już sam tytuł wskazuje na zróżnicowanie i wieloznaczeniowość dzisiejszej kultury. Analiza Krajewskiego jest przede wszystkim bardziej współczesna i oparta na latach wcześniejszych obserwacji. To, na co warto zwrócić uwagę w tekście Krajewskiego, to jego przekonanie, że nie jest kwestią kluczową, jakie treści przekazuje nam kultura, tylko 
jak my z niej korzystamy. Jednak nie należy tutaj mylić poziomu intelektualnego odbiorcy z jego kompetencjami kulturowymi, które mogą być nabywane przez lata, a mimo wszystko być niewystarczające. Dlatego tak ważny jest świadomy odbiorca potrafiący dokonywać filtracji oraz segregacji treści kultury. Świadomy uczestnik kultury korzysta z jej dóbr, jednak nie jest w niej całkowicie zanurzony.

Oczywiście opisując aspekty kultury popularnej nie uciekniemy od kwestii rozrywki czy konsumpcji. U Krajewskiego pojawia się ponadto pojęcie przyjemności oraz zaspokajania potrzeb. Jednak nie mówimy tutaj o zaspokajaniu potrzeb podstawowych, takich jak: głód, pragnienie czy higiena. Wraz z rozwojem kultury masowej i wzrostem popytu na rozrywkę zaczęto wytwarzać sztuczne potrzeby, które wynikają raczej ze świadomości, że dany towar istnieje, niż z powodu faktycznego jego braku w naszym życiu. W końcu jednak te sztuczne potrzeby stają się autentyczne i uczestnik kultury odczuwa poważny dyskomfort z powodu ich braku. Potrzeba staje się przyjemnością. Bardzo ważnym spostrzeżeniem jest także fakt, iż każdy z nas, czyli odbiorców kultury popularnej, jest także jej twórcą, ponieważ akt konsumpcji jest jednocześnie aktem twórczym, a ściślej rzecz ujmując - aktem produkcji.

Krajewski pisze o trzech fazach zmian, którym ulegała kultura popularna, począwszy od jej powstania na przełomie XVIII i XIX wieku (ściśle wiążącego się z postępem technicznym oraz zyskaniem przez klasę robotniczą czasu wolnego), poprzez jej umasowienie trwające mniej więcej od końca XIX wieku do połowy wieku XX. Jednak etap, na którym chciałam się skupić, to faza odmasowienia kultury popularnej i popularyzacji rzeczywistości, która trwa właściwie do czasów współczesnych i obecnie można zauważyć jej apogeum. Nadal większość „produktów” kultury popularnej charakteryzuje się niewielkim stopniem dywersyfikacji, otaczają nas głównie podobne do siebie masy. Marek Krajewski (Krajewski, 2003, s. 84) zwraca jednak uwagę na fakt, iż obecnie kultura popularna i konsumpcja stają się coraz mniej homogeniczne oraz wystandaryzowane. Co więcej, coraz dokładniej przenikają wszystkie sfery życia. Nie jest już wymagane, żeby kultura była jednolita, zintegrowana i wspólna dla wszystkich jako potwierdzenie wyrównania poziomu życia społeczeństwa. Nastąpiła pluralizacja kultury i postępuje jej różnicowanie. Obecnie częściej kładziony jest nacisk na poszukiwanie własnej tożsamości i tzw. bycie sobą w przestrzeni publicznej oraz manifestowanie swojej odrębności. Niemniej jednak dalej odbywa się to za pośrednictwem procesu produkcji i dystrybucji dóbr, których posiadanie zaczęło wyrażać jednostkową niepowtarzalność. Pozytywny aspekt dzisiejszej kultury to na pewno powszechność kształcenia, ponieważ odbiorca lepiej wykształcony ma większe potrzeby kulturalne. Staje się także bardziej wybredny. 
W tekście Arendt pojawia się stwierdzenie, że wytwór kultury charakteryzuje się pięknem. Zresztą do niedawna większość z nas tak właśnie zdefiniowałaby dzieło sztuki. W takim razie według niektórych odbiorców część współczesnych produktów kultury w ogóle nie zasługuje na miano „dzieła sztuki”. Arendt zauważyła, że kultura masowa opanowała do perfekcji podrabianie wytworów kultury wyższej i sprowadzanie ich do formy kiczu. Dlatego piękno nie może być już wyznacznikiem zakwalifikowania czegoś jako dzieła sztuki. Z jednej strony odbiorca może mieć do czynienia z czymś miłym dla oka, jednak może się to okazać repliką. Z drugiej zaś strony coraz częściej otacza nas sztuka awangardowa, która niekoniecznie musi się podobać, ale z kolei nas porusza. Pojawia się zatem stwierdzenie gustu i smaku, ponieważ tylko wtajemniczeni odbiorcy, dysponujący odpowiednim kapitałem kulturowym i intelektualnym, mogą czerpać z kultury popularnej najbardziej wartościowe treści. Obecnie coraz częściej mówi się o filozoficznym podejściu do sztuki. Ma ona działać na nasz intelekt i zmuszać do myślenia. Aby to robić nie musi być tylko pięknym obrazem. Może wręcz przeciwnie - powinna szokować i sprawiać, że wolelibyśmy odwrócić wzrok, ale jednocześnie dzięki temu zwraca na siebie uwagę i zmusza do przemyśleń. Dlatego też bardzo ciężko jest uciec od słów Marschalla McLuhana, że to środek przekazu sam jest przekazem. Sama forma, w jakiej treść jest przekazywana, jest istotą samego przekazu. Właśnie ze względu na ważność środka przekazu we współczesnym świecie takie znaczenie dla kultury popularnej ma audiowizualność. Już na początku XX wieku, kiedy to kluczowe znaczenie miało zaspokajanie potrzeb (już wtedy sztucznie wytwarzanych), zaczęto zwracać uwagę na wizualną stronę sprzedaży towaru. To wtedy pojawiły się wielkie okna sklepowe, a w nich kolorowe wystawy. Także w owych czasach zaczęto budować wielkie galerie handlowe przepełnione kolorowymi towarami. Kluczowy dla dystrybucji tych towarów stał się również rozwój reklamy.

Współczesne środki przekazu, takie jak: telewizja, radio czy Internet, opierają się na powszechnej umiejętności mówienia, czytania i pisania. Jednak same posługują się złożonymi blokami sytuacyjnymi, które angażują zarazem wzrok, jak i słuch. Poza tym wymagają od nas także interpretacji nie tylko werbalnej, ale i audiowizualnej właśnie. Owa percepcja audiowizualna ma ogromny wpływ na kształtowanie się postaw odbiorczych, których rozróżnia się dwa typy. Pierwsza postawa aktywna i krytyczna charakteryzuje się całościowym postrzeganiem przekazu, relacyjnym stylem myślenia oraz wysoką kompetencją komunikacyjną. Postawa ta ułatwia rozszyfrowanie złożonych mechanizmów znaczeniowych, również tych ukrytych założeń manipulacyjnych, a także odróżnia porządek fikcyjny od realnego. Druga postawa jest z kolei pasywna i bezrefleksyjna, towarzyszy jej 
percepcja fragmentaryczna oraz mozaikowy styl myślenia. Jednak przede wszystkim charakteryzuje się małymi kompetencjami komunikacyjnymi (Hopfinger, 1997, s. 23). Postawa ta czyni odbiorcę bezbronnym wobec skomplikowanych zabiegów manipulacyjnych. Kształtowanie tych postaw jest szczególnie ważne we współczesnym procesie kształcenia, ponieważ wszyscy jesteśmy uczestnikami kultury popularnej, niezależnie od tego, jak każdy członek społeczeństwa jest do niej przygotowany. To, na co warto także zwrócić uwagę, to fakt iż we współczesnej kulturze czasami nie sposób jest oddzielić twórcy od odbiorcy kultury. Dlatego też podobnie jak w przypadku zanurzenia w kulturze masowej, kiedy to niezbędne są kompetencje społeczne, aby się w niej nie zatracić, podobnie i w styczności z audiowizualnością - najważniejsze to nie pozwolić całkowicie się od niej uzależnić, kiedy to w sytuacji braku bodźców wizualnych pojawia się swoisty niepokój. Dzisiaj różne kultury potrafią modelować wyposażenie antropologiczne. Stąd też pojęcie syndromu audiowizualnego, kiedy to informacje płynące $\mathrm{z}$ różnych źródeł, różnymi kanałami są przetwarzane przez integrujący mechanizm odbiorczy w audiowizualny kompleks znaczeniowy (Hopfinger, 1997, s. 61).

Mimo że to przede wszystkim kino było pionierem w rozpowszechnianiu audiowizualności od początków XX wieku, to jednak telewizja zawładnęła współczesnym społeczeństwem, zabiegając o rozwój własnego języka oraz specyficznych sposobów wypowiedzi. Telewizja stała się niekwestionowaną potęgą ze względu na znaczenie polityczne, propagandowe czy społeczne. Jest jednak popularna przede wszystkim ze względu na swoją zróżnicowaną ofertę, która obejmuje zarówno rozrywkę, informację, dokument i fabułę, programy popularnonaukowe, jak i różnego rodzaju quizy. A przy tym ma podstawową cechę, jaką jest swoboda wyboru. Tym bardziej jest to zauważalne współcześnie. Teraz nasza swoboda nie ogranicza się tylko do możliwości zmiany kanału w dowolnym momencie przy użyciu pilota i wyboru programu spośród setek dostępnych. XXI wiek to rozwój telewizji internetowej, a także VOD (video on demand), czyli telewizji na żądanie. Daje ona możliwość nie tylko wyboru interesującego nas programu, ale przede wszystkim jego rejestrację i odtworzenie w dogodnym momencie.

Technika i możliwość rejestracji narusza ustalony dotąd porządek, kiedy to obowiązywał ścisły podział na kulturę i naturę. Do tej pory to, co było audiowizualne, charakteryzowało się ulotnością i niepowtarzalnością. Obecnie natomiast utrwalenie to odsłania audiowizualność zachowań ludzkich oraz uczy nas interpretacji zachowań niewerbalnych obok werbalnych. Dla nieprzygotowanego widza uczestnictwo w owej kulturze może być równoznaczne z uczeniem się na błędach i kroczeniem przez życie po omacku. Rozumienie świata opiera się głównie na przyjmowaniu tego, co już jest człowiekowi znane. Jednak jak artykulacja rze- 
czywistości może się odbywać prawidłowo, jeśli główny sposób jej odbioru jest bierny i bezrefleksyjny? Idealny uczestnik kultury audiowizualnej powinien się charakteryzować postawą aktywną i krytyczną. Jednak obecnie nie ma możliwości ani czasu zdobywania potrzebnego do tego doświadczenia. Zmiany zachodzą zbyt szybko.

Dziś (...) przyspieszony rytm życia, nawał informacji, szybkie przemiany, a także niezwykła mobilność ludzi, swoista dostępność dawnych epok i odległych krain, przenikanie się kultur, dostęp do komunikacji w skali globalnej inaczej wyznaczają horyzont przestrzenno-czasowy naszego życia; zwielokrotniają intensywność doznań i przeżyć. Dzisiaj nie tylko powinniśmy umieć poruszać się intuicyjnie w obrębie własnej kultury, intuicja bowiem obecnie nie wystarcza. Musimy poza tym, jak sądzę, być świadomi istnienia naszych norm i wzorów zachowań, uczyć się komunikacyjnych reguł, znać napięcia i mechanizmy naszej kultury, by trafnie się w niej poruszać. Powinniśmy jej prawidła nie tylko wyczuwać, lecz także rozumieć po to, by w obliczu niezwykłej współcześnie dyfuzyjności kulturowej obronić własną integralność kulturową, własną tożsamość (Hopfinger, 1997, s. 66).

Kolejnym problemem, który pojawił się wraz z ekspansją kultury audiowizualnej, jest coraz częstsza praktyka symulowania rzeczywistości oraz jej wirtualizacja. Współczesna cyfryzacja świata wprowadza efekt realności, bez konieczności jej rzeczywistego istnienia (Hopfinger, 1997, s. 65). Daje ona całkowitą swobodę twórcy, który oczywiście w znacznym stopniu może działać według zasady reprodukcji, na której opiera się kultura audiowizualna. Jednak coraz częściej mówi się o „śmierci realności” w następstwie rozwoju technologii (Hopfinger, 1997, s. 68). Można powiedzieć, że to kolejny etap w ewolucji kultury audiowizualnej, kiedy to przestaje być ona odbiciem świata naturalnego. Następuje tu odejście od reprodukcji rzeczywistości. Nadszedł czas rzeczywistości, którą kreuje sam uczestnik kultury popularnej. Warto przy tym zagadnieniu przytoczyć pojęcie hiperrzeczywistości Jeana Baudrillarda oraz symulakry i symulacji. Wyróżniającą cechą naszej epoki jest dominacja obrazu, zajmującego centralne miejsce formy kulturowej. Symulakry, w przeciwieństwie do czegoś realnego, mają sens sam w sobie, bez odniesienia się do czegokolwiek poza nimi (Baudrillard, 2005). Także Piotr Sztompka w swoich rozważaniach zauważa, że cały dzisiejszy świat, który staje się coraz bardziej widowiskowy, nasycony jest treściami wizualnymi, a obrazowość naszego otoczenia zwiększa się. W epoce wizualnej obrazy mają wielkie znaczenie w komunikacji międzyludzkiej, ale także są nośnikami infor- 
macji i wartości. Cywilizacja wizualna porozumiewa się za pomocą szyldów, reklam i plakatów. Staliśmy się społeczeństwem ikonograficznym, w którym obraz konstruuje nasze postrzeganie świata i komunikację (Sztompka, 2012).

W przedstawionej przez Marylę Hopfinger rzeczywistości pytanie o miejsce teatru w kulturze audiowizualnej może wydawać się nie na miejscu. Teatr w końcu opiera się przede wszystkim na interakcji człowieka z drugim człowiekiem. Podstawową cechą teatru, jako praktyki komunikacyjnej, jest bezpośredni kontakt między uczestnikami przedstawienia (Hopfinger, 1997, s. 59). Istnieje on tylko dzięki umowie społecznej mówiącej o wkroczeniu widza w świat fikcji, który przemija, co więcej jest niepowtarzalny i zasada reprodukcji nie ma w świecie teatru racji bytu. Wszakże nie ma dwóch takich samych przedstawień ani dwóch identycznie zagranych ról.

Twórczość teatralna opiera się głównie na kulturze słowa, czyli na twórczości literackiej. Mimo ewidentnej dominacji kultury audiowizualnej we współczesnym świecie sztuka teatralna potrafiła odnaleźć swoje miejsce. Można tutaj wspomnieć chociażby o teatrze telewizji. Mimo że jest to dosyć wyszukana forma rozrywki i na pewno nie najbardziej popularna wśród mas, to zajmuje ona ważne miejsce w programie współczesnej telewizji, natomiast reżyserowanie i uczestnictwo w spektaklu telewizyjnym jest dla samych twórców nie lada wyróżnieniem. Przekształca się także sam teatr, starając się sprostać wymaganiom widza wychowanego w kulturze audiowizualnej. W obliczu wyzwań stawianych współczesnym twórcom coraz częściej literackie motywy przekładane są na obrazy. Jako przykład chciałam przywołać tutaj spektakl teatralny pt. Dziady w reżyserii Radosława Rychcika, który wystawiany jest w Teatrze Nowym w Poznaniu.

Ten młody reżyser zdecydował się na zrobienie czegoś zaskakującego, a mianowicie stworzył Dziady amerykańskie. Genialne dzieło Adama Mickiewicza wyreżyserowane przez Rychcika zostaje przepuszczone przez uniwersalny filtr popkultury. Mogłoby się zdawać, że spotkanie Mickiewicza z amerykańską popkulturą nie może się udać. Wydaje się, że nasze kultury, nawet współcześnie, są tak odmienne, że niemożliwe jest, aby symbolika dramatu z XIX wieku mogła znaleźć swoje odpowiedniki w zmcdonaldyzowanym społeczeństwie. Zestawienie problemu rasizmu z twórczością naszego narodowego wieszcza wydaje się być zabiegiem co najmniej ciekawym. Jednak już od pierwszych scen spektaklu widz zapomina o tych różnicach. To, czego po inscenizacji Dziadów raczej mogliśmy się nie spodziewać, to fakt, iż mówią o wykluczeniu i segregacji rasowej. Interesujące jest to, jak Mickiewicz może być uniwersalny, kiedy okazuje się, że konotacje amerykańskie w ogóle nie przeszkadzają dramatowi romantycznemu, a wręcz przeciwnie, wydobywają z niego nieznane walory (Szczepanik, 2014). Co ciekawe, 
analizując spektakl, możemy dojść do wniosku, iż już nie pierwszy raz reżyser próbuje wykorzystać treść tego dramatu dla ukazania ówczesnych dylematów kulturowych czy też napięć politycznych. Można tutaj przywołać chociażby Dziady w reżyserii Kazimierza Dejmka z 1967 roku wystawiane w Teatrze Narodowym w Warszawie, gdzie główną, obecnie uważaną za kultową, rolę zagrał Gustaw Holoubek. Spektakl ten, zdjęty z afisza po zaledwie jedenastu przedstawieniach - został uznany za „antyradziecki”. Sam Władysław Gomułka nazwał go „nożem w plecy przyjaźni polsko-radzieckiej”. Zresztą wydarzenia te stały się impulsem do późniejszych studenckich protestów i początkiem wydarzeń marcowych 1968 roku.

Jednak skupmy się na Dziadach poznańskich z 2014 roku. Przedstawienie zaczyna się już na ulicy przed wejściem do teatru, gdzie przechodnie i widzowie mogą spotkać czarnoskórą kobietę przypominającą żebraczkę. Śpiewa ona coś na kształt pieśni pogrzebowych. Już wtedy widz może się domyślać, że jest to część spektaklu, chociaż bardziej przypomina performance. Z kolei we foyer teatru czeka na nas również ciemnoskóry boy hotelowy i obsługa z popcornem, jakby żywcem wyjęta z kina ze złotej ery Hollywood. Już pierwsza scena wprowadza widza w konsternację. Postać Jokera z filmów o Batmanie rozpoczyna spektakl piosenką śpiewaną w języku angielskim. Nagle zaczyna deklamować najbardziej chyba rozpoznawalne zdanie z całego utworu Mickiewicza. Po pewnym czasie dołącza do niego postać Marylin Monroe wcielająca się w rolę Ewy. Zestawienie to jest tym bardziej nietypowe, jeśli weźmiemy pod uwagę fakt, iż Ewa w utworze Adama Mickiewicza była przedstawiona jako dusza czysta, niemalże krystaliczna. Kłóci się to nieco z wizerunkiem Marilyn Monroe, która była uznana za symbol seksu w XX wieku. Spektakl rozpoczynają dwa symbole kultury amerykańskiej, gwiazda kina oraz postać z komiksu. To, na co warto zwrócić uwagę, to fakt iż Rychcik nie zmienia ani jednego zdania z oryginalnego tekstu. Oczywiście skraca niektóre fragmenty, jednakże robi to umiejętnie i dzięki temu unika nużących dłużyzn. Po otwarciu kurtyny oczom widza ukazuje się jeszcze bardziej zaskakujący obraz. Scena jest boiskiem do koszykówki, na którym odbywa się mecz, odbiorca dostrzega też automat do coca-coli. Zresztą napój ten zdaje się niemalże nieustannie obecny na scenie, aż można odnieść wrażenie, że reżyser głównie z nim utożsamia Stany Zjednoczone. Kiedy już nasz wzrok ogarnie wszystkie elementy scenografii, nagle widz uświadamia sobie, że jego oczom ukazuje się prawie wzorcowy obraz popkultury amerykańskiej w erze jej największego rozkwitu. Zapewne tak większość z nas wyobraża sobie Amerykę, mając w głowie obrazy z hollywoodzkich filmów. Na scenie są zarówno kultowe postaci z kinematografii, takie jak bliźniaczki z Lśnienia Stanleya Kubricka symbolizujące Józia i Rózię z Dziadów, jest już wspomniana wcześniej Marylin Monroe jako Ewa oraz Joker 
jako Guślarz. Są także koszykarze i cheerleaderka z opaską na oku, która z jednej strony przypomina postać jakby z amerykańskich filmów dla nastolatków, a z drugiej bohaterkę Kill Bill'a Quentin’a Tarantino. Zresztą nie tylko w tej postaci można dostrzec fascynację Rychcika tym amerykańskim reżyserem tworzącym filmy na granicy kiczu, uznawane jednak za kultowe i przepełnione symboliką amerykańskiej popkultury. Te wszystkie postacie wpłynęły znacząco nie tylko na amerykańską kulturę, ale także na naszą. W ogóle zestawione w spektaklu postacie są bardzo znamienne dla nurtu popkultury, który wydaje się być kojarzony tylko z przyjemnością i rozrywką. Nam natomiast zostają pokazane osoby, nieszczęśliwe, które zostały zamordowane lub popełniły samobójstwa, takie jak prezydent John Kennedy czy Marilyn Monroe.

W spektaklu bohaterowie dramatu Mickiewicza przeplatają się z postaciami kultury masowej XX wieku. Każda z tych współczesnych postaci zajmuje pewne miejsce w popkulturze. Wraz z oglądaniem spektaklu oraz z przeplataniem się bohaterów literackich z tymi współczesnymi można dostrzec wspólne cechy, które łączą wszystkie osoby. Czasami ma się wrażenie, że te podobieństwa są aż zbyt oczywiste. Możliwe, że założeniem reżysera było spojrzenie na bohaterów literackich z perspektywy znanych nam współcześnie symboli kultury masowej. Warto zwrócić uwagę na postać Gustawa-Konrada, którego aktor zinterpretował jako zblazowanego, zarośniętego hippisa (lub współcześnie bardziej na miejscu byłoby słowo „hipster”) co chwila popijającego coca-colę, który gdzieś w naszej polskiej podświadomości przypomina lidera zespołu Dżem. Reżyser miał też ciekawy pomysł na zaprezentowanie Wielkiej Improwizacji, na którą zapewne większość widzów czeka z niecierpliwością. I tutaj kolejne wielkie zaskoczenie, gdyż na czas jej wygłaszania sala teatralna pogrąża się w ciemnościach i nagle widzowie słyszą tekst recytowany przez Gustawa-Konrada, ale deklamowany przez wspomnianego już wcześniej Gustawa Holoubka, wykonany niemalże bezbłędnie w filmie Tadeusza Konwickiego pt. Lawa z 1989 roku. W tej chwili widz może czuć się zdezorientowany. Odbiera tylko bodźce audialne, brakuje zaś tych wizualnych. Możliwe, że reżyser w ten sposób chce, aby odbiorca skupił się tylko na treści utworu, a nie obrazie. Rychcik zestawia naszą narodową przemowę ze słynnym „I have a dream” Martina Luthera Kinga z 1963 rok, wygłoszoną przez współczesnego Gustawa-Konrada granego przez Mariusza Zaniewskiego, która stała się manifestem zwolenników równouprawnienia. Zestawienie tych dwóch mów ze sobą może tylko podkreślać, jak ważna dla narodu polskiego może być Wielka Improwizacja, jeśli porównuje się ją do przemowy, która porwała miliony.

Sam problem równouprawnienia jest świetnie zauważalny w scenie ze Złym Panem (w przedstawieniu jego postać ucharakteryzowana jest na plantatora bawełny 
z nieodłącznym batem), kiedy obecni wcześniej przed teatrem oraz we foyer czarnoskórzy aktorzy, niczym Mickiewiczowskie ptaki, krzyczą „Nie lubisz umierać z głodu” w odpowiedzi na jego prośby o uwolnienie duszy. Momentami wydaje się, że poruszony przez reżysera problem segregacji rasowej i nietolerancji dla osób o odmiennym kolorze skóry jest tylko wymówką dla ukazania dosłownie popkulturowej kalki amerykańskiej. Ale Rychcik właśnie pokazuje, że ta kultura wcale nie jest tak idealna, jakby mogły wskazywać na to jej symbole, co chwila wkraczające na scenę. Reżyser stara się pokazać pewną dychotomię świata, który dzieli się na wyzyskujących i wyzyskiwanych, na uciskających i uciskanych. Dlatego właśnie ta Ameryka jest dla nas symbolem wolności i równouprawnienia, ale jednocześnie pokazuje, że do takiego stanu rzeczy dochodzi się latami. W końcu może i polskie społeczeństwo pozwoli dojść do głosu także innym, wykluczonym i nieco nadal obcym w naszym otoczeniu. Może dlatego właśnie tekst Mickiewicza jest tu jak najbardziej na miejscu. Gdyby jakiś Amerykanin, zanurzony w popkulturze USA, zapytał się o treść samego dzieła, którego tekst jest hermetyczny i hermeneutyczny dla polskiej duszy narodowej, wydawać by się mogło, że adekwatna i zwięzła translacja na inną kulturę wydaje się niemożliwa (Drygas, 2015). Jednak Rychcik zdecydował się podjąć to wyzwanie i mimo że momentami sztuka może wydawać się niespójna, to jest to najlepszy przykład przełożenia wielkiego, klasycznego dzieła na bardziej współczesny audiowizualnie i symbolicznie język popkultury.

Audiowizualność to zjawisko, od którego we współczesnej kulturze nie sposób uciec, podobnie jak od samej kultury masowej, która nie ogranicza się już tylko do rozrywki, ale każdy element naszego świata, od edukacji, przez życie rodzinne, na pracy kończąc, zanurzony jest w popkulturze. Obecny w danej kulturze repertuar wartości i ich hierarchie określają styl kultury. Współczesne nam wartości to przede wszystkim potrzeba nadążenia za informacjami i zachodzącymi zmianami. Audiowizualny typ kultury podważa dotychczas utrwalony porządek kultury werbalnej. Co prawda nadal to przede wszystkim język naturalny pełni podstawowe funkcje metasystemowe. To, co jednak zostało zakwestionowane, to jego hegemonia we współczesnej społecznej komunikacji. Słowo i obraz, które do tej pory wydawały się statyczne, uległy zdynamizowaniu oraz stały się ważnymi nośnikami znaczeń. Zjawisko, takie jak teatr, tak solidnie zakorzenione w tradycji, jawi się na szczęście jako praktyka audiowizualna. Współcześnie tekst, obecny na przykład w książkach czy czasopismach, utracił swoją centralną pozycję. Można zaryzykować stwierdzenie, że jego miejsce aktualnie zajęły obraz i dźwięk. Jednak spektakl Radosława Rychcika jest dowodem na to, że odpowiednio użyta symbolika popkultury może być aktualna nawet w tak klasycznym dziele, jakim są Dziady Mickiewicza. Między innymi dzięki takim twórcom jest nadzieja, iż 
teatr, który odgrywa tak istotną rolę edukacyjną poprzez kształcenie wielostronne, będzie nadal zaspokajał potrzeby psychiczne i estetyczne współczesnego widza w kulturze audiowizualnej.

\section{Bibliografia}

Arendt, H. (2011). Między czasem minionym a przyszłym. Warszawa: Aletheia.

Baudrillard, J. (2005). Symulakry i symulacja. Warszawa: Wydawnictwo Sic!

Drygas, P. (2015). Polish Romanticism's pop story. „Dziady” Radosława Rychcika [Relacja z Warszawskich Spotkań Teatralnych]. Pobrane z: http://kulturaliberalna.pl/2015/04/14/ polish-romanticism-rychcik-dziady-recenzja-drygas/.

Hopfinger, M. (1997). Kultura audiowizualna u progu XXI wieku. Warszawa: Instytut Badań Literackich PAN.

Krajewski, M. (2003). Kultury kultury popularnej. Poznań: Wydawnictwo Naukowe UAM. Macdonald, D. (1953). Theory of Mass Culture. Diogenes, 3

Szczepanik. E. O wykluczeniu i segregacji rasowej. Pobrane z: http://www.teatrdlawas. pl/recenzje/1324-o-wykluczeniu-i-segregacji-rasowej.

Sztompka, P. (2012). Socjologia wizualna. Fotografia jako metoda badawcza. Warszawa: PWN. 